\title{
ABCB1 3435TT and ABCG2 421CC genotypes were significantly associated with longer progression-free survival in Chinese breast cancer patients
}

\author{
Wanjun $\mathrm{Li}^{1, *}$, Dan Zhang ${ }^{2, *}$, Fen $\mathrm{Du}^{3, *}$, Xuemei Xing ${ }^{4}$, Ying $\mathrm{Wu}^{5}$, Dong $\mathrm{Xiao}^{6}$, Ming \\ Liang ${ }^{6}$, Zhigang Fan ${ }^{2}$, Peng Zhao ${ }^{7}$, Tao Liu ${ }^{8}$ and Guoyin $\mathbf{L i}^{1,9}$ \\ ${ }^{1}$ Department of Pathology, Hanzhong 3201 Hospital Affiliated to Xi'an Jiaotong University, Xi'an, Shaanxi, China \\ ${ }^{2}$ Department of Oncology, Hanzhong 3201 Hospital Affiliated to Xi'an Jiaotong University, Xi'an, Shaanxi, China \\ ${ }^{3}$ Department of Nursing, Hanzhong Vocational Technical College, Hanzhong, Shaanxi, China \\ ${ }^{4}$ Department of Clinical Laboratory, Hanzhong 3201 Hospital Affiliated to Xi'an Jiaotong University, Xi'an, Shaanxi, China \\ ${ }^{5}$ Department of Breast and Vascular Surgery, Xijing Hospital, The Fourth Military Medical University, Xi'an, Shaanxi, China \\ ${ }^{6}$ Department of General surgery, Hanzhong 3201 Hospital Affiliated to Xi'an Jiaotong University, Xi'an, Shaanxi, China \\ ${ }^{7}$ Department of Hematology, Hanzhong 3201 Hospital Affiliated to Xi'an Jiaotong University, Xi'an, Shaanxi, China \\ ${ }^{8}$ Department of Ophthalmology, Hanzhong 3201 Hospital Affiliated to Xi'an Jiaotong University, Xi'an, Shaanxi, China \\ ${ }^{9}$ Department of Biochemistry and Molecular Biology, The Fourth Military Medical University, Xi'an, Shaanxi, China \\ *These authors are co-first authors \\ Correspondence to: Tao Liv, email: taoliustone@163.com \\ Guoyin Li, email: guoyin0604@163.com
}

Keywords: breast cancer; ABCB1 C3435T and ABCG2 C421A; single nucleotide polymorphism; mutation rate; progression-free survival

Received: August 09, $2017 \quad$ Accepted: September 22, $2017 \quad$ Published: October 31, 2017

Copyright: Li et al. This is an open-access article distributed under the terms of the Creative Commons Attribution License 3.0 (CC BY 3.0), which permits unrestricted use, distribution, and reproduction in any medium, provided the original author and source are credited.

\section{ABSTRACT}

Objective: To investigate the distribution of $A B C B 1$ C3435T and ABCG2 C421A gene polymorphisms in Chinese Han population and their influences on the susceptibility and prognosis of breast carcinoma.

Methods: A total of $\mathbf{2 0 0}$ female subjects were enrolled in this study, comprising 100 breast cancer patients and 100 healthy controls. Carcinoma and para-carcinoma tissues were collected from the breast cancer patients, while peripheral blood was collected from healthy controls. Single nucleotide polymorphisms (SNPs) were detected by the Taqman method. Progression-free survival (PFS) and 5-year survival rate of the patients were calculated.

Results: ABCB1 C3435T and ABCG2 C421A polymorphisms were not associated with disease susceptibility and 5-year survival rate in the study population $(p>0.05)$. However, a high mutation rate of both ABCB1 C3435T and ABCG2 C421A (16\% and $17 \%$, respectively) was observed in breast cancer tissues. Patients with $A B C B 1$ 3435TT genotype or ABCG2 421CC genotype had longer PFS $(p<0.05)$.

Conclusion: $A B C B 13435 T$ and $A B C G 2$ 421CC were significantly associated with longer PFS in Chinese breast cancer patients.

\section{INTRODUCTION}

Breast carcinoma is the leading cause of cancerrelated death among female patients with malignant tumors worldwide [1]. The morbidity and mortality rates of breast carcinoma have steadily increased since 1980s [2]. In the past few decades, great progress has been made in the treatment of breast cancer, particularly in the field of 
chemotherapy. However, treatment efficacy varies greatly due to the inherent genetic heterogeneity of individuals.

Efflux of agents from oncocyte by ATP-binding cassette $(\mathrm{ABC})$ transporter is the most predominant and common mechanism of multiple drug resistance (MDR) among carcinoma [3]. In humans, $49 \mathrm{ABC}$ genes have been reported and classified into seven different families [4, 5]. However, $\mathrm{ABC}$ gene subtypes involved in drug efflux from human cells do not belong to any particular family. For example, 12 transporters have been reported to regulate drug efflux; however, permeability glycoprotein (P-gp/ $\mathrm{ABCB} 1)$, multidrug resistance protein (MRP1/ABCC1), and breast cancer resistance protein (BCRP/ABCG2) are important for the efflux of a variety of drugs [3].

Human $A B C B 1$ gene is located in chromosome region $7 \mathrm{q} 21$; this gene encodes a transmembrane transporters of $170 \mathrm{kDa}$ that acts as an efflux pump for a variety of environmental carcinogens and antineoplastic drugs and plays an important role in resulting MDR of tumors [6-9]. Previous studies have shown that 66 coding single-nucleotide polymorphisms (SNPs) in $A B C B 1$ gene have been identified, including 22 synonymous mutations and 44 non-synonymous mutations [10]. Several studies suggested that the expression level of $A B C B 1$ gene was influenced by its polymorphism status [11,12]. One of the most critical $A B C B 1$ gene polymorphism is C3435T (rs1045642). Although it is a synonymous mutation, C3435T can alter the mRNA expression level of $A B C B 1$, protein activity, and substrate specificity [13-15]. The variant allele frequency of $\mathrm{C} 3435 \mathrm{~T}$ is significantly different among various populations and races [16].

Human $A B C G 2$ gene is located in chromosomal region 4q22 and encodes a 72-kDa membrane protein [17]. $\mathrm{ABCG} 2$ can transport numerous substrates, ranging from chemotherapeutics to carcinogenic xenobiotics [18-20]. Thus far, several SNPs in $A B C G 2$ gene have been identified that can alter its expression and functionality [21]. One of the most important $A B C G 2$ gene polymorphisms is C421A (rs2231142). The C421A SNP can lead to a glutamineto-lysine amino acid substitution, resulting in decreased expression and activity of the ABCG2 protein [22-24]. Similar to $\mathrm{C} 3435 \mathrm{~T}$, the mutation rate of C421A in $A B C G 2$ gene is significantly different among different populations [25].

This study investigated the distribution of rs 1045642 and rs2231142 polymorphisms in a Chinese Han breast cancer population who had been treated with postoperative chemotherapy. Correlation between the genetic polymorphism and breast cancer incidence, clinical features, and prognosis were explored.

\section{RESULTS}

\section{Baseline characteristics of study subjects}

The distributions of characteristics of the 100 breast cancer cases and 100 healthy controls are presented in Table 1. There were no significant differences in the distributions of age and menopausal state between cases and controls ( $p=0.571$ and $p=0.48$, respectively), and the average age was matched for breast cancer cases (range, 23-77 years; median, 50 years) and controls (range, 20-75 years; median, 50 years). Of the 100 breast cancer cases, 75 had invasive ductal carcinoma, 20 had invasive lobular carcinoma, and 5 had medullary carcinoma. Furthermore, 63 patients were diagnosed with stage II and 37 patients were diagnosed with stage III. Age at menarche of the patients was 12-18 years old. None of them had family history of breast cancer. Of the patients in our cohort, $70 \%$ / $60 \%$ / 40\% were estrogen receptor (ER) /progesterone receptor (PR) / Her2 positive, respectively. IHC results showed $34 \% / 38 \% / 28 \%$ of patients with low / intermediate / high Ki67 expression. Lymph node metastasis was detected in $52 \%$ of the patients.

\section{Comparison of genotype distribution between patients with breast carcinoma and healthy controls}

Overall genotype and allele frequencies for $A B C B 1$ $\mathrm{C} 3435 \mathrm{~T}$ and $A B C G 2 \mathrm{C} 421 \mathrm{~A}$ polymorphisms in cases and controls are listed in Table 2 and Supplementary Figure 1. The observed genotype frequency among individuals in the control group was in agreement with Hardy-Weinberg equilibrium. There was no significant difference in the distribution of three genotypes (CC, CT, and TT) of $A B C B 1 \mathrm{C} 3435 \mathrm{~T}$ between the breast cancer cases and healthy controls $(p>0.05)$. No significant difference was detected in the distribution of $\mathrm{C}$ and $\mathrm{T}$ alleles between the breast cancer patients and healthy controls $(p>0.05)$. Moreover, we did not find significant difference in the distribution of three genotypes (CC, CA, and $\mathrm{AA}$ ) of $A B C G 1 \mathrm{C} 421 \mathrm{~A}$ between the breast cancer cases and healthy controls $(p>0.05)$. There were no significant difference in the distribution of $\mathrm{C}$ and $\mathrm{A}$ alleles between the breast cancer patients and healthy controls $(p>0.05)$.

\section{Comparison of genotype distribution between breast cancer tissues and adjacent tissues}

Overall genotype and allele frequencies for $A B C B 1$ $\mathrm{C} 3435 \mathrm{~T}$ and $A B C G 2 \mathrm{C} 421 \mathrm{~A}$ polymorphisms in cancer tissues and adjacent tissues are presented in Table 3. The observed genotype frequency among the paracarcinoma tissues was in agreement with Hardy-Weinberg equilibrium. There were no significant difference in the distribution of three genotypes (CC, CT, and TT) of $A B C B 1 \mathrm{C} 3435 \mathrm{~T}$ between the carcinoma and paracarcinoma adjacent tissues $(p>0.05)$. However, we found that $16 \%$ of carcinoma tissues had genetic mutations (Table 4). The mutation rates of CC, CT, and TT genotypes were $15.8 \%, 11.6 \%$, and $26.3 \%$, respectively. Although no significant difference was found in the distribution of three 
Table 1: Demographic and clinicopathological parameters of patients $(n=100)$

\begin{tabular}{|c|c|c|c|}
\hline Characteristic & Case number & Controls number & $\boldsymbol{P}$ \\
\hline \multicolumn{4}{|l|}{ Age (years) } \\
\hline Median & 50 & 50 & \\
\hline Range & $23-77$ & $20-75$ & \\
\hline$<50$ & 44 & 50 & 0.479 \\
\hline$\geq 50$ & 56 & 50 & \\
\hline \multicolumn{4}{|l|}{ Age at menarche (years) } \\
\hline$\leq 14$ & 68 & & \\
\hline$>14$ & 32 & & \\
\hline \multicolumn{4}{|l|}{ Menopausal state } \\
\hline Premenopausal & 48 & 54 & 0.48 \\
\hline Postmenopausal & 52 & 46 & \\
\hline \multicolumn{4}{|l|}{ Reproductive history } \\
\hline One child & 35 & & \\
\hline Two children & 53 & & \\
\hline Three or more children & 12 & & \\
\hline Onset age (year, ${ }^{-} \mathrm{x} \pm \mathrm{s}$ ) & $51.29 \pm 9.48$ & & \\
\hline \multicolumn{4}{|l|}{ Family history } \\
\hline Yes & 0 & & \\
\hline No & 100 & & \\
\hline Five year survival rate & 65 & & \\
\hline \multicolumn{4}{|l|}{ Pathological location } \\
\hline Left breast & 53 & & \\
\hline Right breast & 47 & & \\
\hline \multicolumn{4}{|l|}{ Pathological type } \\
\hline Invasive ductal carcinoma & 75 & & \\
\hline Invasive lobular carcinoma & 20 & & \\
\hline Medullary carcinoma & 5 & & \\
\hline \multicolumn{4}{|l|}{ Clinical stage } \\
\hline II & 63 & & \\
\hline III & 37 & & \\
\hline \multicolumn{4}{|l|}{ Estrogen receptor } \\
\hline+ & 70 & & \\
\hline- & 30 & & \\
\hline
\end{tabular}

Progesterone receptor

$+\quad 60$

$\begin{array}{ll}- & 40\end{array}$

Her2

$\begin{array}{ll}+ & 40\end{array}$ 


\begin{tabular}{|c|c|c|c|}
\hline Characteristic & Case number & Controls number & $P$ \\
\hline- & 60 & & \\
\hline \multicolumn{4}{|l|}{ Ki67 } \\
\hline Low $(<14 \%)$ & 34 & & \\
\hline Intermediate (14\%-30\%) & 38 & & \\
\hline High $(>30 \%)$ & 28 & & \\
\hline \multicolumn{4}{|l|}{ Lymph node metastasis } \\
\hline Node-positive & 52 & & \\
\hline Node-negative & 48 & & \\
\hline \multicolumn{4}{|l|}{ Surgery } \\
\hline Yes & 100 & & \\
\hline No & 0 & & \\
\hline \multicolumn{4}{|l|}{ Postoperative chemotherapy } \\
\hline Yes & 96 & & \\
\hline No & 4 & & \\
\hline
\end{tabular}

Table 2: Genotype and allele frequencies of $A B C B 1 \mathrm{C} 3435 \mathrm{~T}$ and $A B C G 2 \mathrm{C} 421 \mathrm{~A}$ polymorphisms in normal tissues of breast cancer patients and controls

\begin{tabular}{|c|c|c|c|c|c|}
\hline & Variable & No. of cases & No. of controls ${ }^{\mathrm{a}}$ & P-value ${ }^{b}$ & OR $(95 \% \text { CI })^{\mathrm{c}}$ \\
\hline \multirow{8}{*}{$\begin{array}{l}A B C B 1 \\
\text { C3435T }\end{array}$} & Allele & & & & \\
\hline & $\mathrm{C}$ & 122 & 120 & - & - \\
\hline & $\mathrm{T}$ & 78 & 80 & 0.919 & $1.043(0.698-1.557)$ \\
\hline & Genotype & & & & \\
\hline & $\mathrm{CC}$ & 40 & 35 & - & \\
\hline & $\mathrm{CT}$ & 42 & 50 & 0.353 & $1.361(0.738-2.508)$ \\
\hline & $\mathrm{TT}$ & 18 & 15 & 1 & $0.952(0.419-2.166)$ \\
\hline & $\mathrm{CT}+\mathrm{TT}$ & 60 & 65 & 0.559 & $1.238(0.698-2.197)$ \\
\hline \multirow{8}{*}{$\begin{array}{l}A B C G 2 \\
\mathrm{C} 421 \mathrm{~A}\end{array}$} & Allele & & & & \\
\hline & $\mathrm{C}$ & 135 & 133 & & \\
\hline & A & 65 & 67 & 0.915 & $1.046(0.69-1.587)$ \\
\hline & Genotype & & & & \\
\hline & $\mathrm{CC}$ & 47 & 46 & - & \\
\hline & CA & 41 & 41 & 1 & $1.022(0.564-1.85)$ \\
\hline & $\mathrm{AA}$ & 12 & 13 & 1 & $1.107(0.457-2.678)$ \\
\hline & $\mathrm{CA}+\mathrm{AA}$ & 53 & 54 & 1 & $1.041(0.597-1.815)$ \\
\hline
\end{tabular}

OR: odds ratio, $\mathrm{CI}$ : confidence interval

a The observed genotype frequency among individuals in the control group was in agreement with Hardy-Weinberg equilibrium. $\left(\mathrm{p}^{2}+2 \mathrm{pq}+\mathrm{q}^{2}\right)=1 ; \chi^{2}=0.174, p=0.677$ for $A B C B 1(\mathrm{C} 3435 \mathrm{~T}) ; \chi^{2}=0.636, p=0.425$ for $A B C G 2(\mathrm{C} 421 \mathrm{~A})$.

${ }^{\mathrm{b}} \mathrm{P}$ values were calculated from two-sided chi-square tests for either genotype distribution or allele frequency

${ }^{c} \mathrm{OR}$ and $95 \% \mathrm{CI}$ values were calculated by unconditional logistic regression adjusted for age and menopausal state. 
Table 3: Genotype and allele frequencies of $A B C B 1 \mathrm{C} 3435 \mathrm{~T}$ and $A B C G 2 \mathrm{C421} \mathrm{A}$ polymorphisms in cancer tissues and adjacent tissues

\begin{tabular}{|c|c|c|c|c|c|}
\hline & Variable & No. of cancer tissue & No. of adjacent tissue ${ }^{a}$ & P-value ${ }^{b}$ & OR $(95 \% \text { CI })^{\mathrm{c}}$ \\
\hline \multirow{8}{*}{$\begin{array}{l}\text { ABCB1 } \\
\text { C3435T }\end{array}$} & Allele & & & & \\
\hline & $\mathrm{C}$ & 119 & 122 & - & - \\
\hline & $\mathrm{T}$ & 81 & 78 & 0.838 & $0.939(0.629-1.402)$ \\
\hline & Genotype & & & & \\
\hline & $\mathrm{CC}$ & 38 & 40 & - & - \\
\hline & CT & 43 & 42 & 0.876 & $0.928(0.502-1.716)$ \\
\hline & $\mathrm{TT}$ & 19 & 18 & 0.843 & $0.9(0.411-1.969)$ \\
\hline & $\mathrm{CT}+\mathrm{TT}$ & 62 & 60 & 0.885 & $0.919(0.521-1.623)$ \\
\hline \multirow{8}{*}{$\begin{array}{l}\mathrm{ABCG} 2 \\
\mathrm{C} 421 \mathrm{~A}\end{array}$} & Allele & & & & \\
\hline & $\mathrm{C}$ & 134 & 135 & - & - \\
\hline & A & 66 & 65 & 0.915 & $\begin{array}{c}1.023(0.674- \\
1.553)\end{array}$ \\
\hline & Genotype & & & & \\
\hline & $\mathrm{CC}$ & 52 & 47 & & \\
\hline & $\mathrm{CA}$ & 30 & 41 & 0.214 & $\begin{array}{c}1.512(0.818- \\
2.795)\end{array}$ \\
\hline & AA & 18 & 12 & 0.534 & $\begin{array}{c}0.738(0.322- \\
1.692)\end{array}$ \\
\hline & $\mathrm{CA}+\mathrm{AA}$ & 48 & 53 & 0.572 & $\begin{array}{c}1.222(0.701- \\
2.128)\end{array}$ \\
\hline
\end{tabular}

OR: odds ratio, CI: confidence interval

${ }^{a}$ The observed genotype frequency among cases in the adjacent tissues was in agreement with Hardy-Weinberg equilibrium. $\left(\mathrm{p}^{2}+2 \mathrm{pq}+\mathrm{q}^{2}\right)=1 ; \chi^{2}=1.375, p=0.241$ for $A B C B 1(\mathrm{C} 3435 \mathrm{~T}) ; \chi^{2}=0.429, p=0.512$ for $A B C G 2(\mathrm{C} 421 \mathrm{~A})$. ${ }^{\mathrm{b}} \mathrm{P}$ values were calculated from two-sided chi-square tests for either genotype distribution or allele frequency ${ }^{c} \mathrm{OR}$ and $95 \% \mathrm{CI}$ values were calculated by unconditional logistic regression adjusted for age and menopausal state.

genotypes (CC, CA, and AA) of $A B C G 2 \mathrm{C} 421 \mathrm{~A}$ between the cancerous tissues and adjacent tissues $(p>0.05), 17 \%$ mutation rate was detected in the cancerous tissues. The mutation rates of $\mathrm{CC}, \mathrm{CA}$, and $\mathrm{AA}$ genotypes were $1.9 \%$, $43.3 \%$, and $22.2 \%$, respectively.

\section{Relation between genotype distribution and clinicopathological characteristics}

Clinicopathological features of the patients were distinguished according to $A B C B 1 \mathrm{C} 3435 \mathrm{~T}$ and $A B C G 2$ C421A genotypes and are shown in Table 5. Chi-square tests or Fisher's exact test was used to assess the effect of the SNPs on the clinicopathological characteristics of the 100 breast cancer patients. We found that there was no significant correlation between genotype distribution of $A B C G 2$ and age at diagnosis, menopausal state, age at menarche, histology, clinical stage, lymph node metastasis, Ki67 expression level, ER status, PR status, or HER2 status. We also investigated the effect of $A B C B 1 \mathrm{C} 3435 \mathrm{~T}$ genotype distribution on the above clinicopathological features, and only clinical stage and Ki67 expression level were significantly associated with $A B C B 1 \mathrm{C} 3435 \mathrm{~T}$ genotype. Moreover, we detected that the distribution frequency of the $A B C B 1 \mathrm{C} 3435 \mathrm{~T} \mathrm{CC}$ genotype was lower among the cases diagnosed with stage II than stage III $(p=0.018$ and OR $(95 \%$ CI $) 0.34(0.146-0.793))$. Based on our research, compared to patients with intermediate/ high expression of Ki67, patients with low expression of Ki67 showed a significant reduction in mutation rate of ABCB1 C3435T $(p<0.001$ and OR $(95 \%$ CI $) 4.656$ (1.922-11.279)).

\section{Association between $A B C B 1$ and $A B C G 2$ gene variants and patient survival}

To investigate the association between $A B C B 1$ $\mathrm{C} 3435 \mathrm{~T}$ and $A B C G 2 \mathrm{C} 421 \mathrm{~A}$ gene polymorphisms and 
Table 4: The mutation rates of $A B C B 1 \mathrm{C} 3435 \mathrm{~T}$ and $A B C G 2 \mathrm{C421 \textrm {A }}$ in breast cancer patients

\begin{tabular}{|c|c|c|c|c|}
\hline & Adjacent tissue & Cancer tissue & & Mutation rate \\
\hline \multirow{7}{*}{$\begin{array}{l}A B C B 1 \\
\text { C } 3435 \mathrm{~T}\end{array}$} & $\mathrm{CC}$ & $\mathrm{CT}$ & 4 & $15.8 \%$ \\
\hline & & $\mathrm{TT}$ & 2 & \\
\hline & $\mathrm{CT}$ & $\mathrm{CC}$ & 1 & $11.6 \%$ \\
\hline & & TT & 4 & \\
\hline & $\mathrm{TT}$ & $\mathrm{CC}$ & 2 & $26.3 \%$ \\
\hline & & $\mathrm{CT}$ & 3 & \\
\hline & Total & & 16 & $16 \%$ \\
\hline \multirow{6}{*}{$\begin{array}{l}A B C G 2 \\
\mathrm{C} 421 \mathrm{~A}\end{array}$} & $\mathrm{CC}$ & AA & 1 & $1.9 \%$ \\
\hline & $\mathrm{CA}$ & AA & 9 & $43.3 \%$ \\
\hline & & $\mathrm{CC}$ & 4 & \\
\hline & $\mathrm{AA}$ & $\mathrm{CA}$ & 2 & $22.2 \%$ \\
\hline & & $\mathrm{CC}$ & 2 & \\
\hline & Total & & 17 & $17 \%$ \\
\hline
\end{tabular}

progression-free survival (PFS) and 5-year survival rate in breast carcinoma patients, the cases were followed up for 5 years. We observed that patients with TT genotype showed significantly longer PFS than patients harboring $\mathrm{CC}$ genotype in $A B C B 1 \mathrm{C} 3435 \mathrm{~T}$ ( $\mathrm{p}=0.03$ ). There was no statistically significant difference in PFS between the patients with the $\mathrm{CC}$ genotype and those with the $\mathrm{CT}$ genotype in $A B C B 1 \mathrm{C} 3435 \mathrm{~T}$ ( $\mathrm{p}>0.05)$. Moreover, there was no significant association between the genotype of $A B C B 1 \mathrm{C} 3435 \mathrm{~T}$ and the 5-year survival rate of breast cancer patients (Figure 1, $\mathrm{p}>0.05$ ). We also detected that patients with $C C$ genotype had significantly longer PFS than patients with 421AA genotype in $A B C G 2$ $(\mathrm{p}=0.012)$. However, there was no significant difference in PFS between the patients with CC genotype and those harboring the CA genotype in $A B C G 2 \mathrm{C} 421 \mathrm{~A}(\mathrm{p}>0.05)$. There was no significant association between the polymorphism of $A B C G 2 \mathrm{C} 421 \mathrm{~A}$ and the 5-year survival rate of breast cancer patients (Figure 1, $\mathrm{p}>0.05$ ).

\section{DISCUSSION}

Gene polymorphism plays a vital role in human phenotypic variability including cancer susceptibility and patient response to therapy. In recent decades, considerable progress has been made in the study of the polymorphism of tumor-resistance genes. $A B C B 1$ and $A B C G 2$ have been extensively studied as important resistance genes. Previous studies have shown that the polymorphisms of $A B C B 1$ and $A B C G 2$ can alter the mRNA expression levels and protein activity $[11,12,21]$. The $\mathrm{C} 3435 \mathrm{~T}$ polymorphism in $A B C B 1$ is a synonymous mutation that can alter its mRNA expression level, protein activity, and substrate specificity [13-15]. The C421A polymorphism in $A B C G 2$ can lead to a glutamine-to-lysine amino acid substitution, resulting in the decrease of its expression level and protein activity [22-24]. In this study, we examined the genotype frequencies of $A B C B 1 \mathrm{C} 3435 \mathrm{~T}$ and $A B C G 2 \mathrm{C} 421 \mathrm{~A}$ distribution in Chinese female breast cancer patients and healthy controls.

The frequencies of the CC, CT, TT genotype of $\mathrm{C} 3435 \mathrm{~T}$ in the breast cancer cases were $40 \%, 42 \%$, and $18 \%$, and in the healthy controls, the frequencies were $35 \%, 50 \%$, and $15 \%$, respectively. Our results suggested that there was no significant association between $A B C B 1$ C3435T polymorphism and the breast cancer susceptibility in Chinese women $(p>0.05)$. Tatari et al. also reported that $A B C B 1 \mathrm{C} 3435 \mathrm{~T}$ polymorphism was not associated with breast cancer susceptibility in Iran [26]. Gervasini et al. found no association between $A B C B 1 \mathrm{C} 3435 \mathrm{~T}$ polymorphism and risk of lung cancer [27]. In contrast, Siegsmund et al. reported that in renal cell carcinoma patients, the frequency of the exon 26 C3435T allele was significantly higher than the normal population [28]. The study of Jamroziak et al. in acute lymphoblastic leukemia showed that the $A B C B 13435 \mathrm{TT}$ genotype was associated with the occurrence of ALL. Wu et al. found that the frequency of the homozygous variant TT genotype of C3435T in breast carcinoma patients was significantly higher than in controls [29]. The difference in tumor type and patient ethnicity may contribute to these inconsistent findings. The frequencies of the $\mathrm{CC}$, $\mathrm{CA}$, and AA genotype of C421A in the breast carcinoma patients were $47 \%, 41 \%$, and $12 \%$, while $46 \%, 41 \%$, and $13 \%$ in healthy controls, respectively. However, our findings suggested that $A B C G 2 \mathrm{C} 421 \mathrm{~A}$ polymorphism 
Table 5: Correlation of clinical characteristics of $A B C B 1 \mathrm{C} 3435 \mathrm{~T}$ and $A B C G 2 \mathrm{C} 421 \mathrm{~A}$ polymorphisms in patients with breast cancer

\begin{tabular}{|c|c|c|c|c|c|c|c|c|}
\hline \multirow[t]{2}{*}{ Characteristics } & \multicolumn{4}{|c|}{$A B C B 1 \mathrm{C} 3435 \mathrm{~T}$} & \multicolumn{4}{|c|}{$A B C G 2 \mathrm{C} 421 \mathrm{~A}$} \\
\hline & $\begin{array}{c}\mathrm{CC} \\
\text { (No.) }\end{array}$ & $\begin{array}{c}\text { CT+TT } \\
\text { (No.) }\end{array}$ & $P^{a}$ & $\begin{array}{c}\text { OR }^{b} \\
(95 \% \mathrm{CI})\end{array}$ & $\begin{array}{c}\mathrm{CC} \\
\text { (No.) }\end{array}$ & $\begin{array}{c}\mathbf{C A}+\mathbf{A A} \\
(\mathbf{N o})\end{array}$ & $P^{a}$ & $\begin{array}{c}\text { OR }^{b} \\
(95 \% \mathrm{CI})\end{array}$ \\
\hline \multicolumn{9}{|l|}{ Age (year) } \\
\hline$<50$ & 16 & 28 & \multirow{2}{*}{0.765} & \multirow{2}{*}{$\begin{array}{c}0.883 \\
(0.391-1.996)\end{array}$} & 23 & 21 & \multirow{2}{*}{0.961} & \multirow{2}{*}{$\begin{array}{c}1.02 \\
(0.463-2.248)\end{array}$} \\
\hline$\geq 50$ & 22 & 34 & & & 29 & 27 & & \\
\hline \multicolumn{9}{|l|}{ Menopausal state } \\
\hline Premenopausal & 18 & 30 & \multirow{2}{*}{0.921} & \multirow{2}{*}{$\begin{array}{c}0.96 \\
(0.428-2.155)\end{array}$} & 25 & 23 & \multirow{2}{*}{0.987} & \multirow{2}{*}{$\begin{array}{c}1.006 \\
(0.459-2.207)\end{array}$} \\
\hline Postmenopausal & 20 & 32 & & & 27 & 25 & & \\
\hline \multicolumn{9}{|l|}{ Pathological type } \\
\hline IDC & 32 & 43 & \multirow{2}{*}{0.125} & \multirow{2}{*}{$\begin{array}{c}2.357 \\
(0.845-6.572)\end{array}$} & 39 & 36 & \multirow{2}{*}{1} & \multirow{2}{*}{$\begin{array}{c}1 \\
(0.404-2.474)\end{array}$} \\
\hline Others & 6 & 19 & & & 13 & 12 & & \\
\hline \multicolumn{9}{|l|}{ Clinical stage } \\
\hline II & 18 & 45 & \multirow{2}{*}{0.018} & \multirow{2}{*}{$\begin{array}{c}0.34^{*} \\
(0.146-0.793)\end{array}$} & 35 & 28 & \multirow{2}{*}{0.41} & \multirow{2}{*}{$\begin{array}{c}1.471 \\
(0.651-3.324)\end{array}$} \\
\hline III & 20 & 17 & & & 17 & 20 & & \\
\hline \multicolumn{9}{|l|}{$\begin{array}{l}\text { Lymph node } \\
\text { metastssis }\end{array}$} \\
\hline Node-negative & 16 & 32 & \multirow{2}{*}{0.412} & \multirow{2}{*}{$\begin{array}{c}0.682 \\
(0.302-1.539)\end{array}$} & 23 & 25 & \multirow{2}{*}{0.548} & \multirow{2}{*}{$\begin{array}{c}0.73 \\
(0.332-1.604)\end{array}$} \\
\hline Node-positive & 22 & 30 & & & 29 & 23 & & \\
\hline \multicolumn{9}{|l|}{ ER } \\
\hline- & 13 & 17 & \multirow{2}{*}{0.506} & 1.376 & 12 & 18 & 0121 & 0.5 \\
\hline+ & 25 & 45 & & $(0.575-3.292)$ & 40 & 30 & 0.131 & $(0.209-1.194)$ \\
\hline PR & & & & & & & & \\
\hline- & 15 & 25 & 1 & 0.965 & 18 & 22 & 0300 & 0.626 \\
\hline+ & 23 & 37 & 1 & $(0.423-2.202)$ & 34 & 26 & 0.309 & $(0.28-1.4)$ \\
\hline Her2 & & & & & & & & \\
\hline- & 25 & 35 & 0405 & 1.484 & 30 & 30 & 0685 & 0.818 \\
\hline+ & 13 & 27 & 0.400 & $(0.642-3.427)$ & 22 & 18 & 0.085 & $(0.367-1.826)$ \\
\hline Ki67 & & & & & & & & \\
\hline Low $(<14 \%)$ & 21 & 13 & $<0.001$ & 4.656 & 14 & 20 & 0.12 & 0.516 \\
\hline $\begin{array}{l}\text { Intermediate } \\
(14 \%-30 \%) \text { and } \\
\text { High }(>30 \%)\end{array}$ & 17 & 49 & & $(1.922-11.279)$ & 38 & 28 & & $(0.223-1.194)$ \\
\hline
\end{tabular}

OR: odds ratio, $\mathrm{CI}$ : confidence interval

*: $p<0.05$

a $\mathrm{P}$ values were calculated from two-sided chi-square tests or Fisher's exact test

${ }^{\mathrm{b}} \mathrm{OR}$ and $95 \%$ CI values were calculated by unconditional logistic regression adjusted for age and menopausal state.

was not associated with the susceptibility to breast cancer in Chinese women. A number of studies indicated that $A B C G 2$ C421A polymorphism was not associated with the susceptibility to prostate cancer [30], colorectal cancer $[31,32]$. In contrast, some studies suggested that $A B C G 2$ C421A polymorphism may be useful as a biomarker for 
the prediction of susceptibility to diffuse large B-cell lymphoma [33], lymphoma [34], and nonpapillary renal cell carcinoma [35]. Previous studies have shown that the $A B C G 2$ C421A polymorphism varies widely among different tumor types and populations. Nonetheless, research on the correlation of $A B C G 2$ gene polymorphism and breast cancer susceptibility is lacking, which this study attempts to address in a Chinese Han population.

We also detected $A B C B 1 \mathrm{C} 3435 \mathrm{~T}$ and $A B C G 2$ C421A genotypes in the cancerous and normal tissues from breast cancer patients. Interestingly, we found that the cancer tissue of $16 \%$ breast carcinoma patients harbored gene mutations in the $A B C B 1 \mathrm{C} 3435 \mathrm{~T}$ loci. The mutation rate of the $\mathrm{CC}, \mathrm{CT}$, and TT genotype was $15.8 \%$, $11.6 \%$, and $26.3 \%$ respectively. We also found that $17 \%$ of carcinoma cases had gene mutations in $A B C G 2 \mathrm{C} 421 \mathrm{~A}$ loci. The mutation rate of the $\mathrm{CC}, \mathrm{CA}$, and AA genotype was $1.9 \%, 43.3 \%$, and $22.2 \%$ respectively. Therefore, genotype analysis of cancer tissue cannot be replaced by detecting the peripheral blood or normal tissue of patients.

This study analyzed the correlation between the clinicopathological features of breast cancer patients and $A B C B 1 \mathrm{C} 3435 \mathrm{~T}$ and $A B C G 2 \mathrm{C} 421 \mathrm{~A}$ gene polymorphisms.
The frequency of 3435CC genotype in patients with stage III was significantly higher than patients with stage II. Compared to patients with intermediate/high expression of $\mathrm{Ki} 67$, patients with low expression of $\mathrm{Ki} 67$ got a significant higher frequency of 3435CC genotype. Other clinicopathological features in this study were not significantly related to $A B C B 1 \mathrm{C} 3435 \mathrm{~T}$ polymorphisms. Turgut et al. [36], Wu et al.[9] and Macías-Gómezdid et al. [37] reported similar results. The correlation between the clinicopathological features of breast carcinoma in our study, according to $A B C G 2 \mathrm{C} 421 \mathrm{~A}$ polymorphism revealed no significant association at this level. Our results showed that no significant association between $A B C G 2$ C421A polymorphisms and clinicopathological features (age at diagnosis, menopausal state, age at menarche histology, clinical stage, lymph node metastasis, Ki67 status, ER status, PR status, HER2 status) of breast cancer patients. Our results are in agreements with those from Korenaga et al. [35]. We speculate that other factors may obscure the relationship between ABCG2 C421A polymorphisms and clinicopathological characteristics.

All the patients in this study received surgical treatment and postoperative adjuvant chemotherapy. We
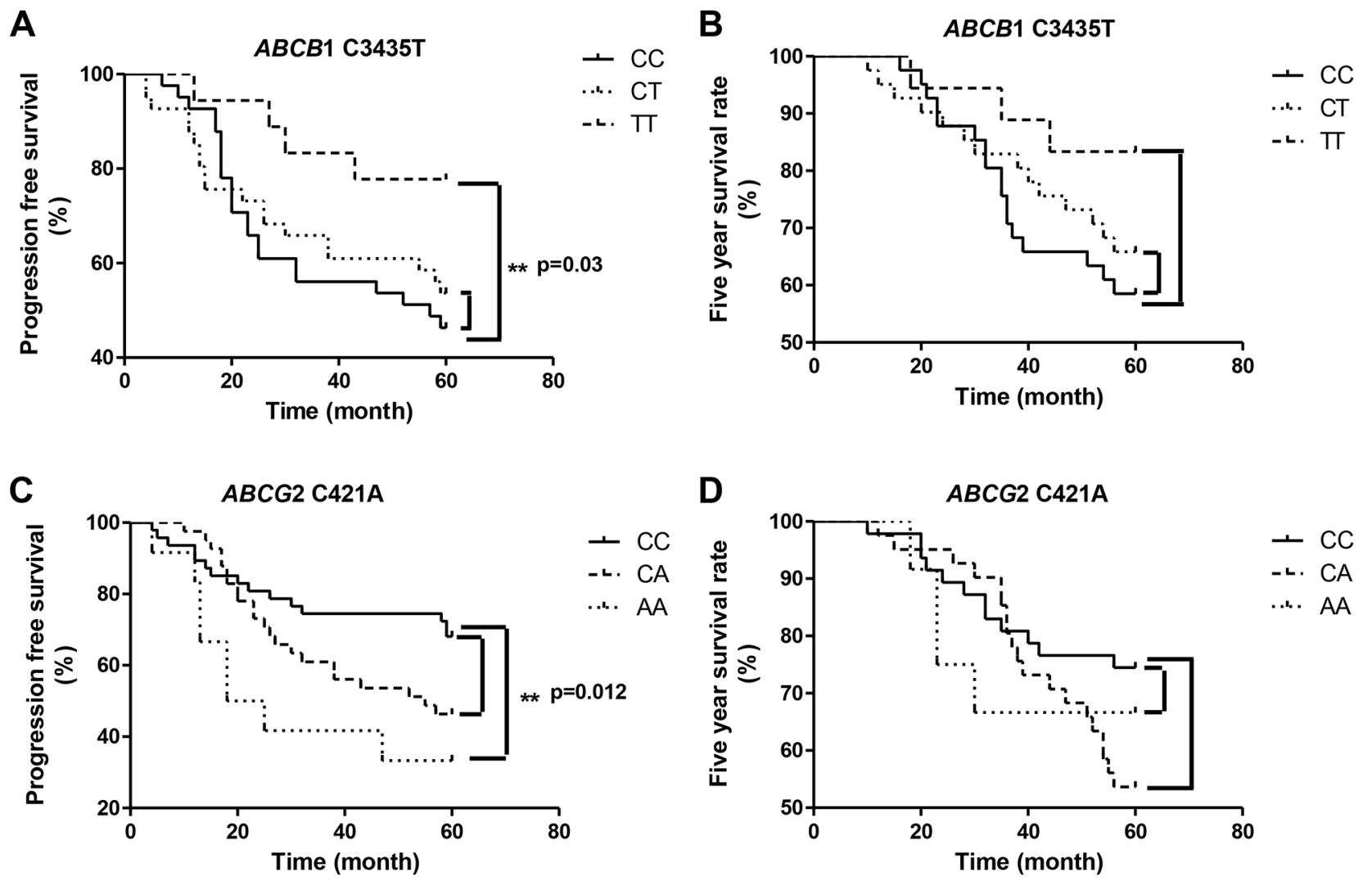

Figure 1: Association between $A B C B 1$ and $A B C G 2$ polymorphism and breast cancer patient survival (A) Association between $A B C B 1 \mathrm{C} 3435 \mathrm{~T}$ polymorphism and progression-free survival. (B) Association between $A B C B 1 \mathrm{C} 3435 \mathrm{~T}$ polymorphism and five year survival rate of the patients. (C) Association between $A B C G 2$ C421A polymorphism and progression-free survival. (D) Association between $A B C G 2 \mathrm{C} 421 \mathrm{~A}$ polymorphism and five year survival rate of the patients. 
Table 6: Univariate and multivariate analysis of PFS in breast cancer patients

\begin{tabular}{|c|c|c|c|c|}
\hline \multirow[t]{2}{*}{ Variables } & \multicolumn{2}{|c|}{ Univariate analyses } & \multicolumn{2}{|c|}{ Multivariate analyses } \\
\hline & Hazard ratio $(95 \% \mathrm{CI})$ & $p$-value ${ }^{\mathrm{a}}$ & Hazard ratio $^{\mathrm{b}}(95 \% \mathrm{CI})$ & $p$-value ${ }^{\mathrm{a}}$ \\
\hline Age & $1.064(0.587-1.928)$ & 0.838 & - & - \\
\hline Lymph node metastssis & $0.852(0.473-1.535)$ & 0.594 & - & - \\
\hline Pathological type & $1.435(0.74-2.84)$ & 0.286 & - & - \\
\hline Clinical stage & $1.073(0.584-1.973)$ & 0.281 & - & - \\
\hline Menopausal state & $0.657(0.342-1.324)$ & 0.246 & - & - \\
\hline ER & $2.136(1.103-4.136)$ & $0.024^{*}$ & $1.787(0.983-3.248)$ & 0.057 \\
\hline PR & $1.836(0.998-3.379)$ & 0.051 & - & - \\
\hline HER2 & $0.666(0.362-1.226)$ & 0.192 & - & - \\
\hline Ki67 & $0.999(0.54-1.847)$ & 0.997 & & \\
\hline$A B C B 1 \mathrm{C} 3435 \mathrm{~T}$ & $2.124(1.035-4.358)$ & $0.04^{*}$ & $1.785(0.753-4.231)$ & 0.188 \\
\hline$A B C G 2 \mathrm{C} 421 \mathrm{~A}$ & $2.039(1.129-3.681)$ & $0.018^{*}$ & $0.577(0.312-1.067)$ & 0.08 \\
\hline
\end{tabular}

OR: odds ratio, $\mathrm{CI}$ : conWdence interval

*: $p<0.05$

${ }^{a} \mathrm{P}$ values were calculated from two-sided chi-square tests or Fisher's exact test

${ }^{\text {b }}$ OR and $95 \%$ CI values were calculated by unconditional logistic regression adjusted for age and menopausal state.

Table 7: Primers and probes used for taqman assays

\begin{tabular}{lcc}
\hline SNP & \multicolumn{1}{c}{ Primer } & Probe \\
\hline \multirow{2}{*}{ rs2231142 } & F:5'-ATGTTGTGATGGGCACTCTG-3' & P-A:TGCTGAGAACTTTAAGT \\
& R:5'-GTCATAGTTGTTGCAAGCCG-3' & P-C:TGCTGAGAACTGTAAGT \\
& F:5'-CCTATGGAGACAACAGCCG-3' & P-T:CCTCACAATCTCTTC \\
rs1045642 & R:5' & \\
& ACTCGATGAAGGCATGTATGTT-3' & P-C:CTCACGATCTCTTC \\
\hline
\end{tabular}

followed up patients for five years, and assessed their progression-free survival and 5-year survival rates. Our results showed that breast carcinoma patients with $A B C B 1$ 3435TT genotype had significantly longer PFS than those with CC genotype. Our results were consistent with the studies of Madrid-Paredes et al[38] and $\mathrm{Wu}$ et al[9]. However, the studies of Cizmarikova et al[39] and Ji et al [40] are inconsistent with our findings. Potentially, the difference in pathological stage and treatment regimen may explain the inconsistent results. We also analyzed the 5-year survival rate of the patients, and found that there was no significant correlation with the polymorphisms of $A B C G 1 \mathrm{C} 34535 \mathrm{~T}$ and $A B C G 2 \mathrm{C} 421 \mathrm{~A}$.

In conclusion, this study found that $A B C B 1 \mathrm{C} 3435 \mathrm{~T}$ and $A B C G 2$ C421A genotypes were not significantly correlation with the susceptibility to breast carcinoma in a Chinese Han population. However, these two loci had a higher rate of mutation in breast cancer tissue. $A B C B 1$ 3435TT and $A B C G 2421 C C$ genotypes were significantly correlated with longer PFS of the breast cancer patients. But the result of multivariate Cox regression analysis suggested that they cannot be used as predictors for the PFS of breast cancer patients (Table 6). Here, we suggest that in detecting breast cancer resistance-related genes, samples should be selected from cancer tissue, and not peripheral blood or normal tissue. Meanwhile, a multigene joint analysis will be better.

\section{MATERIALS AND METHODS}

\section{Study subjects}

In this study, 100 breast cancer patients (female, median age: 50 years, range: 23-77 years) with incident breast carcinoma who were admitted to the 3201 hospital affiliated to Xi'an Jiao Tong University between 2010 and 2016 were enrolled. In addition 100 healthy control subjects (female, median age: 50 years, 
range: 20-75 years) were enrolled. All breast cancer patients underwent surgical treatment. Post-operative chemotherapy was based on a docetaxel and epirubicin regimen. Carcinoma and para-carcinoma tissues were collected from the patients and blood samples were collected from the healthy donors. Malignancy of the carcinoma tissues was confirmed by pathological analysis. The local ethics committee approved the research protocol for this study and all volunteers signed the study informed consent form.

\section{Date collection}

Two clinicians collected clinical features and treatment outcomes from medical records and followed patients on a regular basis. Complete information about the treatment was obtained from all 100 breast carcinoma patients.

\section{DNA extraction}

Paraffiwn-embedded tissue DNA extraction kit (TIANGEN, DP331, China) was used to extract DNA from carcinoma and para-carcinoma tissues. Blood genomic DNA extraction kit (TIANGEN, DP318, China) was used to extract DNA from blood samples. All protocols were in strict accordance with the manufacturers' instructions.

\section{Single nucleotide polymorphism analysis}

The SNPs in $A B C B 1 \mathrm{C} 3435 \mathrm{~T}$ and $A B C G 2 \mathrm{C} 421 \mathrm{~A}$ were detected by Taqman method using the primer sequences and probes shown in Table 7. Each PCR reaction mixture contained 2x Hotstart Fluo-PCR mix 10 $\mu \mathrm{l}$, sense primer $0.5 \mu \mathrm{l}(10 \mu \mathrm{M})$, anti- sense primer $0.5 \mu \mathrm{l}$ $(10 \mu \mathrm{M})$, probe $0.8 \mu \mathrm{l}(10 \mu \mathrm{M})$, template DNA $2 \mu \mathrm{l}(20 \mathrm{ng} /$ $\mu \mathrm{l})$, PCR-grade water $6.2 \mu \mathrm{l}$. The amplification consisted of an initial denaturation step for $4 \mathrm{~min}$ at $95^{\circ} \mathrm{C}$ followed by 40 cycles of melting $95^{\circ} \mathrm{C}$ for $15 \mathrm{~s}$, and annealing/ extension at $60^{\circ} \mathrm{C}$ for $60 \mathrm{~s}$. PCR reactions were carried out in a Roche, LightCycler480 Real-time PCR System.

\section{Immunohistochemical analysis}

A standard protocol was used for the immunohistochemistry (IHC) of the samples that were detected as breast cancer by hematoxylin and eosin staining. Briefly, formalin fixed, paraffin embedding, paraffin-embedded specimens, dewaxing to water, antigen repair, serum blocking, primary antibody incubation (ER antibody, abcam, ab27595; PR antibody, abcam, ab32063; HER2 antibody, abcam, ab16901; Ki67 antibody, abcam, ab8191), secondary antibody incubation, coloration.

\section{Statistical analyses}

All statistical analyses were carried out using Statistical Program for Social Sciences (SPSS) software
17.0 (SPSS Inc., USA). Hardy-Weinberg equilibrium and pairwise haplotype frequencies were estimated using the Hardy-Weinberg calculator and CubeX tools respectively, both provided by the Online Encyclopedia for Genetic Epidemiology studies. Statistical significance was set at $p<0.05$ for all tests, and all tests were twosided. Chi-square (Pearson's $\chi^{2}$ test) or Fisher's exact test was used to determine the differences in distributions of demographic, epidemiologic, and clinical variables between the two groups. Survival analysis was performed by Kaplan-Meier method and compared by log-rank test. Factors with significant influence on univariate analysis were further analyzed by multivariate Cox regression analysis. The minimum level of significance was established at $p<0.05$.

\section{Compliance with ethical standards}

The study was approved by the ethics committee of 3201 hospital affiliated to Xi'an Jiaotong University.

\section{ACKNOWLEDGMENTS}

This study was funded by State Key Laboratory of Tumor Biology (CBSKL201601) and Hanzhong 3201 Hospital Research Foundation (3201yk201550, 3201yk201607).

\section{CONFLICTS OF INTEREST}

All of the authors declared that they have no conflicts interest in relation to this study.

\section{REFERENCES}

1. Jemal A, Bray F, Center MM, Ferlay J, Ward E, Forman D. Global cancer statistics. CA Cancer J Clin. 2011; 61:69-90.

2. Xing P, Dong H, Liu Q, Yao F, Xu Y, Chen B, Zheng X, $\mathrm{Wu}$ Y, Jin F, Li J. Impact of persistence on survival of patients with breast cancer treated with endocrine therapy in Northeast China: A prospective study. Oncotarget. 2017; 8:102499-102510. https://doi.org/10.18632/ oncotarget.18454.

3. El-Awady R, Saleh E, Hashim A, Soliman N, Dallah A, Elrasheed A, Elakraa G. The Role of Eukaryotic and Prokaryotic ABC Transporter Family in Failure of Chemotherapy. Front Pharmacol. 2017; 7:535.

4. Dean M, Hamon Y, Chimini G. The human ATP-binding cassette (ABC) transporter superfamily. J Lipid Res. 2001; 42:1007-17.

5. Auner V, Sehouli J, Oskay-Oezcelik G, Horvat R, Speiser $\mathrm{P}$, Zeillinger R. ABC transporter gene expression in benign and malignant ovarian tissue. Gynecol Oncol. 2010; 117:198-201. 
6. Kerb R. Implications of genetic polymorphisms in drug transporters for pharmacotherapy. Cancer Lett. 2006; 234:4-33.

7. Ueda K, Clark DP, Chen CJ, Roninson IB, Gottesman MM, Pastan I. The human multidrug resistance (mdr1) gene. cDNA cloning and transcription initiation. J Biol Chem. 1987; 262:505-08.

8. Zhou SF. Structure, function and regulation of P-glycoprotein and its clinical relevance in drug disposition. Xenobiotica. 2008; 38:802-32.

9. Wu H, Kang H, Liu Y, Tong W, Liu D, Yang X, Lian M, Yao W, Zhao H, Huang D, Sha X, Wang E, Wei M. Roles of ABCB1 gene polymorphisms and haplotype in susceptibility to breast carcinoma risk and clinical outcomes. J Cancer Res Clin Oncol. 2012; 138:1449-62.

10. Wolf SJ, Bachtiar M, Wang J, Sim TS, Chong SS, Lee CG. An update on ABCB1 pharmacogenetics: insights from a 3D model into the location and evolutionary conservation of residues corresponding to SNPs associated with drug pharmacokinetics. Pharmacogenomics J. 2011; 11:315-25.

11. Ieiri I, Takane H, Hirota T, Otsubo K, Higuchi S. Genetic polymorphisms of drug transporters: pharmacokinetic and pharmacodynamic consequences in pharmacotherapy. Expert Opin Drug Metab Toxicol. 2006; 2:651-74.

12. Hoffmeyer S, Burk O, von Richter O, Arnold HP, Brockmöller J, Johne A, Cascorbi I, Gerloff T, Roots I, Eichelbaum M, Brinkmann U. Functional polymorphisms of the human multidrug-resistance gene: multiple sequence variations and correlation of one allele with P-glycoprotein expression and activity in vivo. Proc Natl Acad Sci USA. 2000; 97:3473-78.

13. Hemauer SJ, Nanovskaya TN, Abdel-Rahman SZ, Patrikeeva SL, Hankins GD, Ahmed MS. Modulation of human placental P-glycoprotein expression and activity by MDR1 gene polymorphisms. Biochem Pharmacol. 2010; 79:921-25.

14. Hutson JR, Koren G, Matthews SG. Placental P-glycoprotein and breast cancer resistance protein: influence of polymorphisms on fetal drug exposure and physiology. Placenta. 2010; 31:351-57.

15. Kimchi-Sarfaty C, Oh JM, Kim IW, Sauna ZE, Calcagno AM, Ambudkar SV, Gottesman MM. A "silent" polymorphism in the MDR1 gene changes substrate specificity. Science. 2007; 315:525-28.

16. Tulsyan S, Mittal RD, Mittal B. The effect of ABCB1 polymorphisms on the outcome of breast cancer treatment. Pharmgenomics Pers Med. 2016; 9:47-58.

17. Bailey-Dell KJ, Hassel B, Doyle LA, Ross DD. Promoter characterization and genomic organization of the human breast cancer resistance protein (ATP-binding cassette transporter G2) gene. Biochim Biophys Acta. 2001; 1520:234-41.
18. Mao Q, Unadkat JD. Role of the breast cancer resistance protein (ABCG2) in drug transport. AAPS J. 2005; 7:E118-33.

19. Krishnamurthy P, Schuetz JD. Role of ABCG2/BCRP in biology and medicine. Annu Rev Pharmacol Toxicol. 2006; 46:381-410.

20. Huss WJ, Gray DR, Greenberg NM, Mohler JL, Smith GJ. Breast cancer resistance protein-mediated efflux of androgen in putative benign and malignant prostate stem cells. Cancer Res. 2005; 65:6640-50.

21. Wang C, Xie L, Li H, Li Y, Mu D, Zhou R, Liu R, Zhou K, Hua Y. Associations between ABCG2 gene polymorphisms and isolated septal defects in a Han Chinese population. DNA Cell Biol. 2014; 33:689-98.

22. Kobayashi D, Ieiri I, Hirota T, Takane H, Maegawa S, Kigawa J, Suzuki H, Nanba E, Oshimura M, Terakawa N, Otsubo K, Mine K, Sugiyama Y. Functional assessment of ABCG2 (BCRP) gene polymorphisms to protein expression in human placenta. Drug Metab Dispos. 2005; 33:94-101.

23. Imai $\mathrm{Y}$, Nakane $\mathrm{M}$, Kage $\mathrm{K}$, Tsukahara S, Ishikawa $\mathrm{E}$, Tsuruo T, Miki Y, Sugimoto Y. C421A polymorphism in the human breast cancer resistance protein gene is associated with low expression of Q141K protein and low-level drug resistance. Mol Cancer Ther. 2002; 1:611-16.

24. Mizuarai S, Aozasa N, Kotani H. Single nucleotide polymorphisms result in impaired membrane localization and reduced atpase activity in multidrug transporter ABCG2. Int J Cancer. 2004; 109:238-46.

25. Chen $\mathrm{P}$, Zhao L, Zou P, Xu H, Lu A, Zhao P. The contribution of the ABCG2 C421A polymorphism to cancer susceptibility: a meta-analysis of the current literature. BMC Cancer. 2012; 12:383.

26. Tatari F, Salek R, Mosaffa F, Khedri A, Behravan J. Association of C3435T single-nucleotide polymorphism of MDR1 gene with breast cancer in an Iranian population. DNA Cell Biol. 2009; 28:259-63.

27. Gervasini G, Carrillo JA, Garcia M, San Jose C, Cabanillas A, Benitez J. Adenosine triphosphate-binding cassette B1 (ABCB1) (multidrug resistance 1) G2677T/A gene polymorphism is associated with high risk of lung cancer. Cancer. 2006; 107:2850-57.

28. Siegsmund M, Brinkmann U, Scháffeler E, Weirich G, Schwab M, Eichelbaum M, Fritz P, Burk O, Decker J, Alken P, Rothenpieler U, Kerb R, Hoffmeyer S, Brauch H. Association of the P-glycoprotein transporter MDR1(C3435T) polymorphism with the susceptibility to renal epithelial tumors. J Am Soc Nephrol. 2002; 13:1847-54.

29. Jamroziak K, Młynarski W, Balcerczak E, Mistygacz M, Trelinska J, Mirowski M, Bodalski J, Robak T. Functional C3435T polymorphism of MDR1 gene: an impact on genetic susceptibility and clinical outcome of childhood 
acute lymphoblastic leukemia. Eur J Haematol. 2004; 72:314-21.

30. Gardner ER, Ahlers CM, Shukla S, Sissung TM, Ockers SB, Price DK, Hamada A, Robey RW, Steinberg SM, Ambudkar SV, Dahut WL, Figg WD. Association of the ABCG2 C421A polymorphism with prostate cancer risk and survival. BJU Int. 2008; 102:1694-99.

31. Andersen V, Ostergaard M, Christensen J, Overvad K, Tjønneland A, Vogel U. Polymorphisms in the xenobiotic transporter Multidrug Resistance 1 (MDR1) and interaction with meat intake in relation to risk of colorectal cancer in a Danish prospective case-cohort study. BMC Cancer. 2009; 9:407.

32. Campa D, Pardini B, Naccarati A, Vodickova L, Novotny J, Försti A, Hemminki K, Barale R, Vodicka P, Canzian F. A gene-wide investigation on polymorphisms in the ABCG2/ $\mathrm{BRCP}$ transporter and susceptibility to colorectal cancer. Mutat Res. 2008; 645:56-60.

33. Hu LL, Wang XX, Chen X, Chang J, Li C, Zhang Y, Yang J, Jiang W, Zhuang SM. BCRP gene polymorphisms are associated with susceptibility and survival of diffuse large B-cell lymphoma. Carcinogenesis. 2007; 28:1740-44.

34. Campa D, Butterbach K, Slager SL, Skibola CF, de Sanjosé S, Benavente Y, Becker N, Foretova L, Maynadie M, Cocco P, Staines A, Kaaks R, Boffetta P, et al, and GEC Consortium. A comprehensive study of polymorphisms in the ABCB1, ABCC2, ABCG2, NR1I2 genes and lymphoma risk. Int J Cancer. 2012; 131:803-12.
35. Korenaga Y, Naito K, Okayama N, Hirata H, Suehiro Y, Hamanaka Y, Matsuyama H, Hinoda Y. Association of the BCRP C421A polymorphism with nonpapillary renal cell carcinoma. Int J Cancer. 2005; 117:431-34.

36. Turgut S, Yaren A, Kursunluoglu R, Turgut G. MDR1 $\mathrm{C} 3435 \mathrm{~T}$ polymorphism in patients with breast cancer. Arch Med Res. 2007; 38:539-44.

37. Macías-Gómez NM, Gutiérrez-Angulo M, Leal-Ugarte E, Ramírez-Reyes L, Peregrina-Sandoval J, Meza-Espinoza JP, Ramos Solano F, de la Luz Ayala-Madrigal M, Santoyo Telles F. MDR1 C3435T polymorphism in Mexican patients with breast cancer. Genet Mol Res. 2014; 13:5018-24.

38. Madrid-Paredes A, Cañadas-Garre M, Sánchez-Pozo A, Segura-Pérez AM, Chamorro-Santos C, Vergara-Alcaide E, Castillo-Portellano L, Calleja-Hernández MÁ. ABCB1 $\mathrm{C} 3435 \mathrm{~T}$ gene polymorphism as a potential biomarker of clinical outcomes in HER2-positive breast cancer patients. Pharmacol Res. 2016; 108:111-18.

39. Cizmarikova M, Wagnerova M, Schonova L, Habalova V, Kohut A, Linkova A, Sarissky M, Mojzis J, Mirossay L, Mirossay A. MDR1 (C3435T) polymorphism: relation to the risk of breast cancer and therapeutic outcome. Pharmacogenomics J. 2010; 10:62-69.

40. Ji M, Tang J, Zhao J, Xu B, Qin J, Lu J. Polymorphisms in genes involved in drug detoxification and clinical outcomes of anthracycline-based neoadjuvant chemotherapy in Chinese Han breast cancer patients. Cancer Biol Ther. 2012; 13:264-71. 